\title{
James Stewart and the Changing Face of the Confederate in Mid-Twentieth Century Hollywood Cinema
}

\begin{abstract}
Hollywood cinema offers multifaceted perspectives of the south and the southerner, guided as much by the time of production as by the personnel working on individual movies. This article will focus specifically on two films, fifteen years apart, featuring the same leading actor - James Stewart - in two similar yet distinct portrayals of southerners. The similarities and divergences between the protagonists of Winchester '73 (1950) and Shenandoah (1965) allow us to explore (via a close reading of each text) specifically how the Confederate rebel was constructed for a national audience in the mid-twentieth century, and how that changed across a contested period that saw wide-ranging events in the battle for Civil Rights. Finally, the article shows how debts and divergences from the nineteenth century logics of white supremacy and secessionism factor into particular Hollywood discourses about geography, whiteness, and masculinity and retain an ongoing relevance in the current, fraught political climate.
\end{abstract}

Keywords: South, Confederacy, Hollywood, cinema, western, race politics, Civil War, Civil Rights

Considering James Stewart's distinguished career in the United States Air Force, in which he served in both World War II and Vietnam and reached the rank of Brigadier General, it is perhaps surprising that a selection of his films offers us so much insight into the presentation of a culture that rebelled against the US. Born in 1908 and raised in Pennsylvania, his service beginning in 1941 was to a nation from which, a mere eighty years earlier, the southern states had seceded. However, once Stewart left behind the roles that he had become famous for in the 1930s and 1940s - generally appearing in romantic comedies or dramas as a male lead with an innate civic virtue, such as Martin Breitner in The Mortal Storm (1940) and, perhaps most famously, as Jefferson Smith and George Bailey in the Frank Capra directed Mr. Smith Goes to Washington (1939) and It's a Wonderful Life (1946) respectively - he teamed up with director Anthony Mann to create the western Winchester '73 (1950) and began to take on roles that afforded him the opportunity to present very different leading men. In Winchester '73 he played a former Confederate, while some years later he also portrayed a soldier who similarly took up arms during the Civil War in Shenandoah (1965). This recurrence of related roles allows one to consider through their respective treatments the change in the presentation of the Old South and the southern cause in Hollywood cinema during the middle decades of the twentieth century. The aim of this article is to demonstrate how the fraught political climate of the 1950s and 1960s affects the construction of both the southerner as "leading man," and the South in Hollywood cinema more generally. The article will show that, while never being vilified, the trend is for less sympathetic depictions of southern white men and for more manifest content relating to the politics of the Civil War and its legacies in twentieth century America.

Stewart's first role as a nineteenth-century southerner came in the early 1950s, when the US was fighting the Korean War and, despite a prominent film career, Stewart 
himself was still a military man. Even with the martial elements of his life and the charged political arena of the time, Stewart's first film of the decade seems, despite its historical setting, largely devoid of specific political nuances. Winchester '73, despite being set in the 1870s, bears little trace of the Civil War which had ravaged the United States for the first half of the previous decade. This conflict is absent from the film in any explicit sense, with on-screen clashes stemming not from political allegiances concerning either slavery or states' rights, but primarily from fraternal or racial causes. First and foremost, this is a family revenge narrative, a film about "Stewart's relentless search for [Stephen] McNally, the man who killed their father" (Loy 39). Stephen McNally plays Dutch Henry Brown, the patricidal brother of Stewart's Lin McAdam, and the plot of the film is principally driven through this brotherly strife. There is also peril in the form of Native Americans, but this is again a more strictly racialized enemy than a politicized one. Though reference is made to Crazy Horse and the Battle of Little Bighorn (1876) by the Native character, Young Bull - played by the distinctly unIndian Rock Hudson - these figures are generally "othered" at every opportunity, and exist only as familiar Hollywood stereotypes. Young Bull in particular is, like so many other Hollywood representations of the Indian, "the stoic, silent, strong dark-skinned warrior always ready to kill" (Ono 104). What Hudson lacks in dark skin he makes up for in painted savagery, which is interesting in itself since although "Native Americans had grown accustomed to the film tradition of warpaint ... few would have predicted that this kind of depiction would persist into contemporary times" (Jojola 12). Besides this typical presentation of Young Bull, since after all he is the only Indian with any lines or a significant amount of screen time that we encounter, Indian characters are largely interchangeable. They are gunned down by McAdam and his allies without thought or sympathy, and seem almost to swarm over the heroic whites like insects. This troubling presentation continues when McAdam intentionally aims for Young Bull, and, with their leader killed, the rest of the Indians lose heart and fall back. This has unfortunate parallels with ants; queens must be neutralised in order to successfully manage a colony. There is, at any rate, no investment in a second character who might be considered a suitable leader, and - in a gesture that seems to re-inscribe the logic of white supremacy - with the head of the Indian 'snake' cut off, the rest of the swarm is demoralised and retreats, despite still maintaining huge numerical superiority. The role of the Indian in the film is solely to incite fear in the principally-white audience, at the thought of the technological superiority embodied in the Winchester repeatingrifle falling into their hands of an animalistic crowd. Again, the principle here is the connection between whiteness and manifest destiny, with the fear arising from the threat not only to the central characters, but to the project of Anglo-Saxon dominance of the continent of North America. This film, then, might be thought of as a particularly conservative representation of Native Americans even by the standards of the time, in which there was actually "a reconfiguration particularly marked in 1950s Hollywood" towards more sympathetic portrayals of Native Americans, including in another Stewart movie, Broken Arrow, released the same year as Winchester '73 (Pearson 246).

It is at the point when the peril from this enemy reaches maximum intensity, however, that the veil falls and the United States of the film, as well as Lin McAdam, is shown in an explicitly postbellum context. McAdam and his companion, 'High 
Spade' Frankie Wilson (played by Millard Mitchell), are travellers in the West with no obvious allegiance to anything greater than themselves. When they are pursued across the plains by Native Americans, they shelter in a US army fort. On arrival, they discover that the fort itself is the primary target of the tribe, and that attack will likely come in the morning. McAdam and High Spade predictably join forces with the US Army soldiers to fight off the attack from the racial other, and when the Indian chief is felled by a shot (predictably enough, from McAdam) the charge falters. In the aftermath of the assault, the sergeant in charge remarks to McAdam and Wilson that he "wished we'd have had you at Bull Run. We might not have run so fast." This reference to the first major battle of the Civil War in July 1861, a famous Confederate victory in the face of greater enemy numbers, is followed up by McAdam telling the obviously Unionist Sgt. Wilkes that they were there at Bull Run, before High Spade adds that they were fighting for the victorious Confederacy. Here McAdam fits with the Hollywood convention of protagonists in Westerns as "defeated Southerners taking their battle westward," participants in a logic of cultural geography that places freedom - in this case, from the invading North, reconstruction and racial egalitarianism - on the western frontier (Graham 133).

What is immediately noteworthy is the reaction to this revelation. There is no obvious residue of hostility despite the interlocutors having been on opposite sides of the bloodiest conflict in US history. Instead, there is nothing more than a smile and handshake, before the two heroes are on their way. Upon finding the Winchester ' 73 (from which the film gets its title) on the body of the slain Native chief, rather than keeping it for himself or giving it to one of his own men, the Sergeant bellows after McAdam in order to present him with a trophy for his skill and bravery in the recent engagement. This attempt at communication is unsuccessful, and the rifle is eventually returned through a number of plot contrivances to the villainous Dutch Henry Brown, so that much later in the film McAdam's search for both his treacherous brother and the rifle is unified. In the encounter between north and south, however, what is evident is mutual respect between Wilkes and McAdam, with no evidence of any more fraught feeling. There is also some sort of equivalency here, as the heroic fictional characters of McAdam and Wilson signify the valour and skill displayed by genuine Confederates in turning over superior numbers of Union soldiers. Through this one sentence the abilities of the two are given a firm historical foundation; the implication is that the south was triumphant at Bull Run because they had McAdam and High Spade, or at the very least other men of similar calibre. Each gains something by the comparison - the fictional southern heroes and their skills are inflated by mention of a famous victory, while the Confederates and their cause are romanticised, after the fact, by their connection with heroes of Hollywood. Hernan Vera and Andrew Gordon (264) have argued that much Hollywood cinema focusing on the Civil War dramatized "a split in the white self," between northern and southern, antebellum and postbellum, tolerant and bigoted, and yet in this film it is clear that there is no such interrogation of the politics of whiteness.

Whether or not one wants to take this line of argument quite this far, it is clear that there is no evidence of these characters mirroring their real-world southern counterparts and being, to borrow James C. Cobb's phrase, "defeated and embittered" 
following the conflict (Cobb 68). In reality, "the war and defeat took a terrible toll on the south. From the outset, both sides depicted the conflict as a holy war [and] from the white southerner's perspective, their defeat was more than a lost war; they had evidently fallen out of favor with God" (Goldfield 17-8). Aside from this spiritual desolation, more material factors also conspired against the region: "as northern wealth grew by 50 percent during the 1860 s, southern wealth had declined by 60 percent" (Cobb 67). It is hardly surprising, then, that "Southern bitterness ran deep" (Brogan 351), but the viewer of Winchester '73 would be forgiven for ignorance of any antagonistic feeling or southern hardship. Though in one instance the film acknowledges the existence of the war, but the consequences of the conflict are behind a veil that is never lifted, even temporarily.

It is interesting to note that, although viewers encounter a number of veterans of the Civil War, Winchester '73 has surprisingly little to say about the African American question. In racial terms there is a fear for much of the film that the repeating-rifle will fall into the hands of the "Natives," but there is no mention of the Thirteenth Amendment, or the black slaves that had recently been freed. In the exchange mentioned previously, one might anticipate either a vindication of the white supremacist south by those who supposedly fought for it, or even a demonstration of the righteousness of the Union cause from those who fought in blue. Given the minimizing of the importance of emancipation here, might one see in this an example of "white southerners who had lost the war" seemingly winning the peace? (Cobb 80) The reality is that although southerners embraced the United States in the aftermath of war, they also romanticised rather than rejected their past. As James M. McPherson states,

their glorious forebears had fought courageously for what they believed was right; perhaps they deserved to win; but in the long run it was a good thing they lost. This Lost Cause mentality took on the proportions of a heroic legend, a southern Götterdämmerung with Robert E. Lee as a latter-day Siegfried. (McPherson 854)

Winning the peace involves reorienting the moral compass of the war in this way, so that the philosophical and emotional impact of defeat is lessened. "Southern romanticism had never vanished," and it returned "with particular importance in sentimentalizing the Confederacy" (Wilson 38). The ongoing relevance of these questions is evident not only in the creation of subsequent southern heroes in reactionary movies like The Outlaw Josey Wales (1975) - another film in which a southerner, this time one written by Asa Carter (speechwriter for Governor George Wallace of Alabama) heads to the West following the War - but also in the contemporary debate around the Confederate flag and civil war monuments. One can also see traces of this mythology in the tourism industry around former plantations since "the heritage of the period before the Civil War, often highly romanticised, is an important part of the South's appeal for tourists, usually focusing on the plantation houses of the former slave-owners" (Boniface, Cooper and Cooper 609).

With the heroes of the film now identified not just as southerners, but as rebel soldiers, one must consider exactly what kind of hero James Stewart played in Winchester '73, and what in turn one might infer about Confederates and the southern 
cause. What is clear immediately is that, though he is heroic, there is a violent edge to the character of Lin McAdam. Some of the intense manifestations of his hatred (including the nature of the chase for his brother which causes Wilson to remark that McAdam was beginning to like hunting a man to death) led to "many viewers [being] stunned by the new Stewart hero" (Schoenke 103). At the film's conclusion, McAdam finally avenges the murder of his father by killing his brother. A certain ambiguity surrounding the ending of the film, and the trajectory of the McAdam character once his white whale has been killed, has led to speculation by R. Phillip Loy that Stewart may well be portraying a type four hero (as postulated by Northrop Frye in Anatomy of Criticism [1957]): that is to say, one that is subject to the same weaknesses as other people around them. Frye writes that this type is "superior neither to other men nor to his environment" (Frye 34). He goes on to say that "on this level the difficulty in retaining the word 'hero' ... occasionally strikes an author" (Frye 34). The connection of this latter point with the monomaniacal McAdam is evident. He is driven first and foremost by anger - hardly a gallant position - and one must question both what will happen to the character once the outlet for that emotion no longer exists, and what implicit statements this film makes about this interpretation of masculinity.

Despite the obvious merit in recognising the ambiguous nature of McAdam's quest for vengeance, it is nevertheless clear that the presentation of the central characters is still, essentially, heroic. While High Spade and McAdam are seen as virtuous, the two brothers are cast in a fairly simple binary opposition. Dutch Henry Brown is patricidal and cruel, and while McAdam gives way to some brutal impulses in his quest for revenge, the morality of the pursuit itself is never questioned. The south, with its emphasis on forefathers and "the blood of a self-regarding nobility [which] transmitted the appropriate qualities" of honour and duty (Wyatt-Brown 49), was an excessively patriarchal society even by the standards of the nineteenth century, and so the murderous actions of Dutch Henry Brown represent a particularly grave transgression for a southern male. Despite being seen in a more modern context than that in which it is set, the force of this transgression is still felt on screen as, though one may be discomfited by the intensity of Stewart's chase, viewers are encouraged to empathise with his motives. Not only is the narrative centrality of Stewart's character in the film important, but so too are the respective associations that a contemporary audience would have had concerning the other primary actors. Despite the dubious nature of some of his actions in this film, through his other roles Stewart still has a firm association with civic virtue and with upright morality. His only western by this time, Destry Rides Again (1939), saw him play a principled lawman who wins over a town despite his obstinate refusal to carry a gun. Conversely, the casting of Steven McNally as Dutch Henry Brown has the opposite effect. Stewart had a number of major credits to his name by this point, while McNally had appeared in several films without ever being given star billing. While Stewart had often been shown as a bastion of virtue, McNally was used to playing menacing or sinister characters, such as the rapist Locky McCormick in Johnny Belinda (1948). It is clear, then, that these roles have been cast so that the audience will support the quest for revenge and make the distinction between Dutch Henry Brown's cold-blooded killing and the nobler, avenging bloodlust of Lin McAdam. This can be seen in the words and actions of other characters, too. 
While Mitchell sometimes voices disquiet with the obsession, it is always a complaint about the ferocity of the search rather than any moral quandary regarding the desired end result. The film never questions Stewart's moral authority in his quest to gun down his brother; it is only his methods that sometimes shock.

McAdam's moral ambiguity only ever manifests itself in actions directed towards those characters who are themselves on the wrong side of the law. In other ways, Lin McAdam is an uncritical portrayal of the traditional southern gentleman. This is an idealised figure, one that reflects that "southern men in this period valued honor, martial qualities, and chivalry" (Creech 28). Not only can viewers discern McAdam's martial qualities in his pursuit of Brown, but the last of these characteristics is evident in his dealings with the film's most prominent woman. His attitude towards the character Lola Manners, portrayed by Shelley Winters, is never anything short of chivalrous, and since she is the only woman in the film with significant screen time or dialogue one must assume that this is typical of McAdam's manner towards women. Similarly, we have already seen how the interactions between the US army officers and the one-time rebel are courteous and bounded by honour and respect. Indeed, though the audience is disconcerted by McAdam and his deviations from the established Stewart persona, it is only by his relative ruthlessness in dealing with shady characters and his Ahab-like obsession with tracking down Dutch Henry Brown, and there is clear water between his interactions with those characters who are a force for good in the film, and those with shadier moral and legal alignments.

So although Winchester '73 is set on the frontier and connections back to states in the east of the country are merely implicit, it is clear that Stewart is portraying a fairly typical image of the southerner that had been prevalent in popular discourse for decades. These chivalrous gentlemen had existed in southern plantation literature during the antebellum period, and appeared in greater number following the Civil War in novels by both Northerners and southerners, reflecting what Cobb calls "the apparent nationwide groundswell of sympathy for the New South's version of slavery and the Civil War" (Cobb 80). It is not surprising, then, that with such literary reconciliation during the decades following the conflict, the presentation in Hollywood initially seems to follow suit. Winchester '73 in fact replicates Hollywood conventions of the aristocratic "Old South," that can be observed in films such as the silent-era Cameo Kirby (1914) or, perhaps most famously, the 1939 epic Gone with the Wind; however, an altogether different picture of the southerner can be seen in the most enduring picture of the South come in Stewart's other film Shenandoah, which came in 1965, fifteen years later than Winchester '73.

This dissimilarity might not be apparent at first. Filmed in glorious Technicolor, the picture shows the Shenandoah Valley in Virginia (or, more accurately, the California Santa Clarita valley which stands in for it) as a lush idyll, replete with the pastoral symbols that appear in uncritical southern presentations of the South through the nineteenth century and beyond. The weather is consistently splendid over the gentle landscape of the family farm, which itself is positioned at the quintessentially pastoral intersection between "the pleasures of rural settlement and the threat of loss and eviction" (Williams 17). At first glance, on encountering this presentation of the Shenandoah landscape, one might be inclined to see this as the continuation of 
a postbellum tradition that presents the 'Old South' as Edenic, only despoiled by the coming of war. If Shenandoah were to fully follow this tradition, it would be drawing on a pastoral vision that "was quickly and firmly fixed in the postbellum historical imaginations of many white southerners" (Cobb 74). It is probably these tendencies in the film that led one contemporary reviewer to suggest that the film was "full of clichés and overdone sentimentality behind which at any moment the reviewer expected to hear 'Dixie"” (New York Herald Tribune, July 20 1965).

The politics of this film are not as reactionary as this reviewer implies, however, and above all other figures it is the character portrayed by Stewart that undercuts much of this conventional rhetoric. Indeed, in the film's expository sections the character of Charlie Anderson seems oddly atemporal in a way that suggests historical texts tell us more about their era of production, than the one in which they are set. When he remarks to the Confederate Lt. Johnson that "this war is not mine and I don't take note of it," he speaks not as a contemporaneous zealot on either side but as a man strangely distanced from the conflict. While his son, Jacob, suggests that "anything that concerns Virginia concerns us" and remarks to his father about incursions by both sides upon Anderson land, Charlie remains distant from the conflict, politically neutral so long as his family and lands are left alone.

In his relative neutrality the film might be accused of side-stepping the issue of slavery, though it does receive more explicit treatment here than in Winchester '73. Bertram Wyatt-Brown has noted that "apart from a few lonely dissenters, Southern whites believed (as most people do) that they conducted their lives by the highest ethical standards" (3). Charlie Anderson does offer a muted criticism of slavery, however, one that sets him apart as one of these lonely dissenters and implicitly places him into a dialogue about the nature of race and the interrelation between the races, both with other characters who offer an uncritical southern line and with the world of the mid-1960s. It is worth noting that although "President Truman submitted a civil rights package to Congress in 1948," his efforts initially met with little to no success (Goldfield 246), and the various acts which forced southern states to recognise the rights of their black citizens were all passed between the mid-fifties and mid-sixties, culminating in the 1965 Voting Rights Act which was passed by Congress in the same year that Shenandoah was released. It would be unwise, then, to imagine that social upheaval have had no bearing on the construction of this southern character, particularly in the distance between Anderson's brand of southern heroism and that of Lin McAdam, a character obviously constructed several years prior to that period in which Hollywood, "unable to sustain its romantic vision of the South in the face of graphic news footage from Oxford, Birmingham, and Selma, the studios ceded the territory to television" (Graham 125). Anderson is a different version of the white southern hero not just because we encounter him in the war rather than after it, and because he performs a different function in the narrative, but because discourses surrounding racial politics in America are undergoing significant upheavals at this time.

Few characters in the film are written with Anderson's wisdom, nor do many endorse his political position. Most, including one of his own sons, Jacob Anderson, exist not as detached figures speaking from the time of production but seem to speak with attitudes recognizable from the 1860 s. For example, at one point Jacob confronts 
his father, saying "Now you say it's not our business, not our fight, but we're Virginians and I believe that anything that concerns Virginia concerns us." This is a view that we can clearly identify as existing around the time of the Civil War, typified perhaps in the character of Robert E. Lee. The Union colonel who resigned in order to lead the rebellious forces of his home state is an enduring myth. In an otherwise critical piece Gary W. Gallagher admits that this 'idea that Lee's Virginia identity, as displayed during the secession crisis, holds the key to understanding his life and career retains great vitality' (Gallagher 10). Lee is emblematic of all Virginians, an idealised archetype; as Heidi Beirich and Kevin Hicks suggest, "white Southerners created a narrative around Lee as the perfect, chivalrous, Christian Southern gentleman" (Beirich and Hicks 86). Given the idealisation of figures like Lee, and their choice of region over nation, it is unsurprising that loyalty to the state drove Virginians to take up arms against the US Army. Loyalty to the Commonwealth of Virginia, rather than to the Union, is privileged in Jacob's comment to his father, and this is reminiscent of much southern and in particular, Virginian - thinking in the nineteenth century according to which the war was fought due to Northern aggression towards the southern homeland and way of life. Perhaps the clearest exponent of this position was the South Carolina firebrand John C. Calhoun, whose "basic message ... was that aggression by the government and the North against the rights of the South had reached a point that unless something was done to stop it immediately and decisively ... the South would secede" (Waugh 93). Stewart, however, rejects this militant interpretation, instead effectively declaring that the war is about slavery. After establishing that the family does not own slaves, Charlie Anderson coaxes another son, Henry, suggesting that "I don't see any reason to fight for something I don't believe is right and I don't think a real friend would ask me to." This again seems to be Anderson speaking from the sixties, not least because even Abraham Lincoln did not consider slavery as central to the aims of the war until the second half of the conflict. Lincoln's letter to Horace Greeley of August 22, 1862, in which he states that "If I could save the Union without freeing any slave I would do it" surely both reveals and emphasises the contemporary nature of Anderson's comment. The centrality of abolition to the war effort is an explicitly postbellum notion, and it is these philosophies to which Anderson gives voice here.

One can also see in this gesture a rehabilitation of at least some nineteenthcentury southerners. While Stewart does seem to speak through the screen with a voice from the 1960s, it is unavoidable that he is in fact portraying a landholder from a century earlier. By intimating that none of the Andersons hold slaves, and by suggesting that they see the immoral side of slavery, this film reactivates some tendencies familiar to us from plantation literature and other apologetics for slavery in the nineteenth century. It was not uncommon for literature to play down the extent or the excesses of slavery as a defence of the institution. This was often done either by showing southerners refraining from holding slaves, or by showing benevolent owners, and texts themselves would often admit to the immoralities of slavery, as in Plantation literature or well-meaning "intersectional" novels of the antebellum period. Although it would be a mistake to too closely align the presentation of Charlie Anderson with the position taken by nineteenth-century apologists, one has to wonder whether one of the potential effects of putting a more modern argument into the mouth of Anderson is, 
in fact, to make the two portrayals appear very similar. Perhaps the presentation of the southerner in Shenandoah is, through the unwitting insertion of Northern arguments into a southern mouth, susceptible to the same problematic tropes of representation.

Other southerners, and in particular Confederate troops, are generally not represented in the film in particularly positive fashion. Lt. Johnson, with his appeals to Charlie Anderson to sacrifice his own family for the common cause and suggests that "Virginia needs all her sons," carries with him an aura of threat to the idyll and is, in the early portions of the film, representative of the war's encroachment on the Anderson family farm. The Confederate soldier with the most screen time, however, is Sam - the suitor (and, later, husband) of Anderson's daughter Jennie. Sam is portrayed by Doug McClure, an actor with an array of television credits who was most famous for his depiction of Trampas in the NBC western series The Virginian from 1962-71. To all intents and purposes, Sam seems worthy and devoted. With characteristics not unlike the rowdy Trampas, though, he is more generally a figure of fun for much of the film. While war seems to be educative at some level and he gains a kind of rudimentary wisdom after some military reversals, earlier in the narrative he appears to lack basic common sense. He struggles to understand the advice passed on by Charlie, and his methods of courtship (particularly his admission that he practiced his speech on his horse in order to hone it) are the subject of humour and surreptitious glances between Charlie and his youngest son. Indeed, when the father approves his marriage to Jennie, Sam rides off into the night yelling with delight, prompting Jennie (observing from the window) to note humorously that he will ride for miles before it occurs to him to come back and tell her the good news.

Union soldiers, however, often fare little better in Shenandoah. Again, the Anderson family remains neutral so long as they are left out of the war, but eventually it is federal intervention and the commandeering of the family's horses that draw Stewart's character into conflict with Union forces. Most of the subsequent struggle comes as the family searches for Boy Anderson (portrayed by Phillip Alford), who has been taken prisoner of war by an overly zealous northern patrol. The radicalizing of Anderson and his sons through the actions of northern officers and their allies seems to be suggestive of "the white southerner's almost instinctive resistance to northern intrusion" (Cobb 188); despite any other shifts in characterisation in this respect Anderson's depiction plays into an existing conservative discourse in which white southerners - both in the Civil War and through the civil rights period - are presented as defending the social order of their communities against interference from invading, meddling Northerners. Whatever problems the south faced, the people of the region believed "southerners alone could fix these problems, and they deeply resented Northern interference" in their affairs (Bernath 45). Anderson is content not to fight the Union until it encroaches on his lands; this bears a striking parallel with the attitude of those in seceding states towards northern and federal intervention, the aforementioned innate defiance to intrusion from the North.

Although the Union Army seems little better than the bumbling Confederates for much of the film, it is clear that Stewart's character could be seen as a crystallization of Yankee traits. He seems to have little time for religion or loyalty to God (at one point telling the pastor that he only attends church services because it was his devout 
wife's dying request), nor to his home state, eschewing both in favour of an extreme model of self-sufficiency. Note, for example, Charlie's attempts at saying grace: "Lord, we cleared this land. We ploughed it, sowed it, and harvested it. We cook the harvest. It wouldn't be here and we wouldn't be eating it if we hadn't done it all ourselves. We worked dog-bone hard for every crumb and morsel, but we thank you Lord just the same for the food we're about to eat, amen." There is no respect or veneration for the supernatural or the spiritual here; if thanks are given it is only to his fellow labourers, while reverence for the divine seems to be replaced at some level by self-congratulation. There is some geographical criss-crossing at work here, since, as Michael Hoberman says, "images of stereotypical Yankee hardheadedness and self-sufficiency abound, not only in New England folklore but throughout American storytelling and literary traditions" (Hoberman 68). Meanwhile, Anderson's attitude towards the Commonwealth of Virginia reflects the Jeffersonian and Jacksonian distrust of governmental authority. When Lt. Johnson attempts to recruit the younger Anderson men, Charlie reacts angrily, exclaiming "They don't belong to the state; they belong to me! When they were babies I never saw the state comin' around here with a spare tit!" The implication is clear: the family was raised by his hard work and by that of his wife, not by the state, and as a consequence neither the state nor an abstract southern cause had any claim on his family to compare with his own.

One might observe in Anderson's character some of the traits that would be incorporated in the New South ideology following the Civil War. Critics of the new creed "charged that it was actually motivated by the same 'mammonism' and 'money mania' that was the essence of Yankeeism" (Cobb 70). Whether we see Charlie Anderson as speaking to us from the 1960s, or as a somewhat avant-garde advocate for elements of the New South from the midst of the plantation idyll, is obviously a matter for individual viewers of Shenandoah. What is clear, though, is that somewhere between the films of 1950 and 1965 that have been considered in this essay, something happened to the way in which the figure of the southerner was rendered. While the southern system had gone on largely unimpeded by northern intrusion since the failure of Reconstruction, events such as the Freedom Rides of 1961 laid "bare the violence that had been there all along but had remained hidden from the glare of national publicity" (Goldfield 246-7). In the decades following the Reconstruction the romantic myth of the Lost Cause gained currency and, consequently, most in the northern states were largely unaware that any great social problem existed in the south. Finally, the huge success of the film adaptation of Gone with the Wind "completed the job of wiping out of the public mind the 'northern' view of slavery, civil war, and reconstruction, replacing it with the traditional 'southern' view" (Reddick 14-5).

When Winchester '73 was made, then, the southern view of history still held sway for much of the US. The south was a romantic place, filled with heroes like Lin McAdam. National coverage of the Civil Rights movement shattered this illusion. As Goldfield says, "resistance [to integration] unwittingly revealed the rotted philosophical underpinnings of white supremacy" (Goldfield 248). By the middle of the sixties, for a southerner to have heroic characteristics, he or she could no longer adhere to the ideas of the Old South but must be either a Yankee, ideologically speaking if not by dint of blood, or a willing participant in the implantation of northern ideals in the region. 
Relatively speaking, Lin McAdam is still a fairly romantic character in Winchester '73, drawing on ideas of family honour, chivalry, and the inherent goodness of the lost southern cause. While some of these themes are still present in 1965, Stewart's later portrayal is bound up much more with mercantile concerns, and is more removed from the notion of a collective south than any generation since, interestingly, the one that he is depicting.

It is intriguing, though, to consider the respective fates of the two characters. As shown, the uncertainty of the conclusion of Winchester ' 73 complicates matters. The viewer could easily see Lin McAdam, both fatherless and now brother-less, as lacking direction without the need to take revenge upon his sibling. There is potentially something unsatisfactory in this narrative trajectory, in as much as the hero is ultimately denied closure even once his quest has been completed. This could potentially be interpreted as McAdam's punishment for his own contravention of southern familial codes. While his brother is guilty of the crime of patricide, he, too, is guilty of fratricide in avenging that death. This reading would offer something of a parallel with Shenandoah, since despite Anderson's ability to see through much of the philosophy of those around him, he remains enthralled by this familial link. Nevertheless, his family suffers tragedy on a number of occasions throughout the film. Firstly, his son is imprisoned by the Union army and, on his escape, is virtually press-ganged into the Confederate Army where he is shot in the leg. Two of his sons are killed, as well as his daughter-in-law. His son-inlaw and daughter are separated by the war before their honeymoon. Although the final shot of the film shows Anderson reunited with his youngest son, the number of family members lost in tragic circumstances forms a catalogue of misfortunes. Perhaps this last image reinforces this message, since there is one character treated with complete reverence - the deceased Martha Anderson, wife of Charlie. She is presented (in her absence, at least) as the embodiment of decent southern womanhood ("the southern lady [was] characterized by piety" [Mathews 123]), and it is after talking to her grave that Anderson heads for church where the reunification with his son takes place. Given the order of events, one might see Anderson as being punished for his deviation from southern norms, but when he gives in to one wiser than himself, this pure vision of southern womanhood with strong religious overtones, he is rewarded by the safe return of his youngest son. Regardless of any progressive or Yankee credentials one might ascribe to the film, then, potentially the southern doctrine of faith and family wins out in the end.

Although the figure of the southerner changes dramatically between 1950 and 1965, Bruce Steel Wills has suggested that the conclusion to Shenandoah is "ultimately uplifting" (Wills 3). Perhaps, with the film's release during the commemorations of the centenary of the ending of the Civil War, the goal was not so much to present a liberal polemic but to aim for something with a more universal appeal. In the final analysis, "the picture in the spirit of the national festival took no sides" (Campbell 171). Although our hero is neither southern zealot nor slaveholder, the pragmatic and individualistic Charlie Anderson is ultimately redeemed by an idealised southern woman. At the film's conclusion, he stands in church with his son, and seems to stand for the nation itself as, after all the privations and calamities of war, there is some symbolic joy in the act of familial reunification. Perhaps more significantly in standing for the nation, both 
northern and southern at the moment of this national festival, Anderson exists as one of Vera and Gordon's "sincere fictions of the white self," reunited in fairly uncomplicated fashion, despite the film's clear liberal discourse elsewhere (Vera and Gordon 279).

In the final reckoning, perhaps there is less of a surprising distance between Stewart's upbringing and his military history, and his portrayal of rebellious southerners than one might first imagine. For various reasons, the representation of the South had always been largely depoliticised, and as a result the associations of independent hard work and civic virtue might transfer straightforwardly from Stewart's Pennsylvania background to a certain interpretation of the southern yeoman farmer. What is apparent from considering these two films in close proximity, though, is that Hollywood movies reach into the past for source material, but bring with them contemporary interpretations and the concerns of the national political climate in which they are produced. Taken as a case study, the ways in which these films diverge reveal that what the Civil War meant in American history, and, indeed, what it meant to be a southerner, were contested questions in the middle decades of the twentieth century. Clearly, these questions play out not only in explicit political discourse, but also in the realm of popular culture.

\section{Works Cited}

Beirich, Heidi and Kevin Hicks. "Gender, Sexuality and Neo-Confederacy." NeoConfederacy: A Critical Introduction. Ed. Euan Hague, Heidi Beirich and Edward H. Sebesta. Austin: University of Texas Press, 2008. 76-96. Print.

Bernath, Michael T. Confederate Minds: The Struggle for Intellectual Independence in the Civil War South. Chapel Hill: University of North Carolina Press, 2010. Print.

Boniface, Brian G., Chris Cooper, and Robyn Cooper. Worldwide Destinations: The Geography of Travel and Tourism. 7th ed. London: Routledge, 2016. Print.

Brogan, Hugh. The Penguin History of the United States of America, London: Penguin, 2001.

Campbell Jr., Edward D.C. The Celluloid South: Hollywood and the Southern Myth. Knoxville: University of Tennessee Press, 1981. Print.

Cobb, James C. Away Down South: A History of Southern Identity. New York: Oxford University Press, 2005. Print.

Creech, Joe. "The Price of Eternal Honor: Independent White Christian Manhood in the Late Nineteenth-Century South." Southern Masculinity: Perspectives on Manhood in the South since Reconstruction. Ed. Craig Thompson Friend. Athens: University of Georgia Press, 2009. 25-45. Print.

Frye, Northrop. Anatomy of Criticism: Four Essays. Princeton, NJ: Princeton University Press, 1957. Print.

Gallagher, Gary W. Becoming Confederates: Paths to a New National Loyalty. Athens: University of Georgia Press, 2013. Print.

Goldfield, David. Still Fighting the Civil War: The American South and Southern History. Baton Rouge: Louisiana State University Press, 2002. Print.

Graham, Allison. Framing The South: Hollywood, Television and Race during the Civil 
Rights Struggle. Baltimore, Md.: Johns Hopkins University Press, 2003. Print. Hoberman, Michael. Yankee Moderns: Folk Regional Identity in the Sawmill Valley of Western Massachusetts, 1890-1920. Knoxville: University of Tennessee Press, 2000. Print.

Jojola, Ted. "Absurd Reality II: Hollywood Goes to the Indians." Hollywood's Indian: The Portrayal of the Native American in Film. Ed. Pete Rollins. Lexington: University Press of Kentucky, 2011. 12-26. Print.

Loy, R. Philip. Westerns in a Changing America, 1955-2000. Jefferson, NC: McFarland, 2004. Print.

Mathews, Donald G. Religion in the Old South. Chicago: University of Chicago Press, 1977. Print.

McPherson, James M. Battle Cry of Freedom: The American Civil War. London: Penguin, 1990. Print.

Ono, Kent A. Contemporary Media Culture and the Remains of a Colonial Past. New York: Peter Lang, 2009. Print.

Pearson, Roberta E. "Indianism? Classic Hollywood's Representation Of Native Americans." Classic Hollywood, Classic Whiteness. Ed. Daniel Bernardi. Minneapolis: University of Minnesota Press, 2001. 245-262. Print.

Reddick, Lawrence. "Of Motion Pictures." Black Films and Film-makers: A Comprehensive Anthology from Stereotype to Superhero. Ed. Lindsay Patterson.. New York: Dodd, Mead and Co., 1975. 3-24. Print.

Schoenke, Michael K. “James M. Stewart: An American Original.” Back in the Saddle: Essays on Western Film and Television Actors. Ed. Gary A. Yoggy. Jefferson, NC: McFarland, 1998. 97-112. Print.

Vera, Hernan and Andrew Gordon. "Sincere Fictions of the White Self in the American Cinema: The Divided White Self in Civil War Films." Classic Hollywood, Classic Whiteness. Ed. Daniel Bernardi. Minneapolis: University of Minnesota Press, 2001. 263-280. Print.

Waugh, John C. On the Brink of Civil War: The Compromise of 1850 and How it Changed the Course of American History. Wilmington, DE: Scholarly Resources, 2003. Print.

Williams, Raymond. The Country and the City. New York: Oxford University Press, 1975. Print.

Wills, Brian Steel. Gone with the Glory: The Civil War in Cinema. Lanham, MD: Rowman and Littlefield, 2007. Print.

Wilson, Charles Reagan. Baptized in Blood: The Religion of the Lost Cause, 18651920. Athens: University of Georgia Press, 2009. Print.

Wyatt-Brown, Bertram. Southern Honor: Ethics and Behavior in the Old South. Oxford: Oxford University Press, 2007. Print. 